\title{
Boekbespreking
}

\section{Broodbome - met spesiale verwysing na die Suider- Afrikaanse soorte}

\author{
Outeur - Nat Grobbelaar
}

Broodbome is vir baie mense wêreldwyd 'n passie wat veel meer as 'n pragtige fokusplant in 'n tuin of 'n statussimbool is. Omdat hierdie plante so waardevol is, is daar dikwels koerantberigte oor plante wat uit die natuur of uit tuine gesteel is. Ongeveer die helfte van broodboomspesies is internasionaal as bedreig verklaar en die handel in al die Suid-Afrikaanse spesies word sterk beheer deur internasionale natuurbewaringwetgewing. Die feit dat' $n$ lisensie van natuurbewaring benodig word om plante te vervoer en te besit, beklemtoon die waarde en besondere status van die plante. 'n Boer mag selfs nie op sy eie plaas 'n broodboom uit die veld na sy tuin verplant sonder toestemming nie.

Encephalartos heennanii se waarde word byvoorbeeld bereken as ongeveer R 800 per $\mathrm{cm}$ stamlengte! Omdat broodbome ook belangrike versamelaarsitems is, is daar ' $n$ groot belangstelling in al die verskillende aspekte van broodbome. 'n Mens sou broodbome as die seëls van die plantrykdom kon beskou.

Daar is al verskeie boeke in Suid-Afrika geskryf oor broodbome. Sommige bespreek versamelings wat in sekere botaniese tuine gevind word en ander fokus op plantkundige aspekte. Die boeke van Cynthia Giddy en Douglas Goody het 'n groot bydrae gelewer.

Prof. Nat Grobbelaar is een van Suid-Afrika se mees vooraanstaande plantfisioloë. Hy het baie wye nasionale en internasionale erkenning ontvang van professionele en lekeorganisasies. Hy het in 2002 die eerste uitgawe van die boek self uitgegee, hoofsaaklik vir die leek wat belang stel in 'n wyer en dieper insig in broodbome. Die boek was so populêr dat daar sedert 2002 al vier herdrukke was. Ter wille van die baie Afrikaanssprekende liefhebbers van broodbome is die boek in 2002 in Afrikaans vertaal en is daar sekere verbeterings aangebring in die nuwe uitgawe van 2004. Hierdie boek lewer dus 'n sterk bydrae tot die Afrikaanse wetenskapsterminologie, net soos vorige boeke uit Nat Grobbelaar se pen toe hy hoof van die Departement Plantkunde aan die Universiteit van Pretoria was.

Die boek beslaan 341 bladsye met bykans 200 pragtige foto's en baie nuuswaardighede oor broodbome. Die boek is dus veel meer as 'n beskrywing met mooi foto's van die verskillende taksons. Dit bespreek die plek van broodbome as lewende fossiele in die planteryk, wêreldwye verspreiding en die ernstige natuurbewaringsprobleme en regulasies wat van provinsie tot provinsie verskil.

Die uitwendige kenmerke wat vir identifikasie gebruik word, word met duidelike tekeninge en figure bespreek. Daarna volg al die aspekte wat verband hou met voortplanting. Hier is uiters waardevolle praktiese wenke oor tegnieke wat die beste resultate gee.

In 'n hoofstuk oor kweking word 'n groot verskeidenheid sake hanteer wat wissel van grond, kompos, verplanting, kouebestandheid, bestryding van onkruid, insekte, swamme, bakterieë en virusse. In 'n hoofstuk oor diverse ander aspekte is onder andere interessante geskiedenis opgeteken oor hoe Jan Smuts en ander burgers gedurende die Anglo-Boereoorlog vergiftig is deur broomboomsaad en vasgehou moes word op hulle perde toe hulle moes vlug.

Ongeveer twee derdes van die boek bestaan uit 'n sleutel wat gebruik kan word om die verskillende taksons uit te ken, gevolg deur volledige besprekings met pragtige glanskleurfoto's. Hierdie bespreking sluit ook die habitat van die plant en wenke vir die kweking in.

Die populariteit van die boek is toe te skryf die praktiese waarde daarvan, gebaseer op Nat Grobbelaar se wye kennis van plante, sy kennis [as voormalige president van die Broodboomvereniging] van wat lede van hierdie vereniging wil hê en van sy ondervinding as kweker van broodbome op sy kleinhoewe noord-oos van Pretoria. Die boek is waardevol vir alle liefhebbers van broodbome, vir kwekers en vir nuwelinge in die veld. Uit sy bedankings is dit duidelik hoe wyd hy inligting van verskillende bronne ingesamel het. Selfs 'n lys van pryse van spesies is ingesluit.

Die boek is in vloeiende Afrikaans geskryf sodat elke nuweling wat in broodbome mag belangstel, hierin 'n skat sal vind. Dat Nat Grobbelaar op 78-jarige ouderdom hierdie uitstaande werk gepubliseer het, is 'n voorbeeld vir baie mede-akademielede.

Die boek sal 'n sieraad op elke boekliefhebber se rak wees en kan teen R490 bestel word by natgrob@hotmail.com.

\section{Kobus Eloff}

